This item was submitted to Loughborough's Research Repository by the author.

Items in Figshare are protected by copyright, with all rights reserved, unless otherwise indicated.

\title{
Roma as a political identity: Exploring representations of Roma in Europe
}

\section{PLEASE CITE THE PUBLISHED VERSION}

https://doi.org/10.1177/1468796814542182

PUBLISHER

SAGE $\odot$ The Author

\section{VERSION}

AM (Accepted Manuscript)

\section{PUBLISHER STATEMENT}

This work is made available according to the conditions of the Creative Commons Attribution-NonCommercialNoDerivatives 4.0 International (CC BY-NC-ND 4.0) licence. Full details of this licence are available at: https://creativecommons.org/licenses/by-nc-nd/4.0/

\section{LICENCE}

CC BY-NC-ND 4.0

\section{REPOSITORY RECORD}

McGarry, Aidan. 2014. "Roma as a Political Identity: Exploring Representations of Roma in Europe". Loughborough University. https://hdl.handle.net/2134/34190. 


\title{
Roma as a Political Identity: Exploring Representations of Roma in Europe
}

\begin{abstract}
This article explores some of the myriad representations of Roma in Europe and argues that this proliferation makes it more difficult for policymakers to formulate coherent interventions, for academics to agree on a common conceptual language and for the majority to understand the inter-connected problems facing Roma communities. 'Representations' refers to how the community is understood by itself as well as by others. Whilst no community retains an uncontested image of itself and its identity, Roma communities, have little or no control over how they are represented in the public sphere. Usually, representations of Roma originate and are sustained by non-Romani actors including international organisations, national governments and the majority. Of course, Roma communities have attempted to influence how they represent themselves externally to challenge negative stereotypes and internally, to raise a political consciousness and foster solidarity. Relatedly, the political representation of Roma is particularly important due to their weak political positioning in local, national and transnational contexts but also because it highlights the disparity between contested questions of who Roma are and devising policy interventions to address socio-economic and political exclusion. This article discusses a select number of prevalent Roma representations and links the representation of Roma identity to the public presence and agency of Romani communities.
\end{abstract}

\section{Introduction}

Multiple Roma representations have produced a problem for Roma and for those who support the inclusion of Roma communities. This situation is not necessarily new for groups occupying a nondominant position, such as women who have had to challenge representations which impede the opportunities, rights, and expectations such representations induce. For Roma communities the multiple representations of their group identity is significant not only because of its overwhelmingly negative associations but also because Roma themselves do not have effective formal representation, in terms of voice and presence in public life, in order to challenge dominant understandings of Roma communities held by societies across Europe. As with other political scientists, particularly Martin Kovats, Huub Van Baar and Peter Vermeersch, I am interested in the political representation of Roma and its relationship to identity. It is important to make a distinction between representation of and representation for: the former refers to the construction of Roma identity and how they are seen and understood whilst the latter refers to the capacity of Roma to articulate their voice, make demands and control dominant images of themselves. This article believes the two are linked. Without a presence in public life, the proliferation of Roma representations will continue unabated. I will not evaluate whether such representations are 'true' or not, as I do not think this is possible, nor is it particularly relevant here. The article does seek to explore whether the multiple representations of Roma communities and Roma identity help or hinder the inclusion of Roma communities. Full inclusion means the social, cultural, economic, political and legal integration of Roma communities in all spheres of public life: symbolically and practically, it means full citizenship and requires the recognition and active participation of Roma. It 
argues that different types of representation exist which have an impact on Roma. These representations have been constructed and sustained by elites, academics, etc, in institutional contexts, some of which may also have a Roma heritage.

Any discussion on Roma representations must be aware of the academy's role in shaping dominant understandings so that due consideration can be given to potentially harmful representations. As Tremlett discusses in this volume, there exists significant disagreement on ontological questions such as 'who are Roma?' amongst academics working on Roma. Willems (1998) maintains that there exists an idea of who Roma are. But there are no objective criteria to determine who is Roma because Roma do not all speak the same language or share a common religion, are geographically dispersed with different economic and political experiences, enjoy divergent levels of wealth and education, and retain different cultural practices. That Roma are extremely heterogeneous is widely accepted although when we, as academics, discuss Roma we try to use a common vocabulary. Most academics are careful not to essentialise, even if we do so by deploying concepts and monikers which suggest unity and coherence, such as 'Roma', and most research acknowledges the difficulty of using one appellation to capture a wide variety of individuals and communities. Furthermore, the representation of Roma as having Indian origins (Grellmann, 1787; Hancock, 2000; Marsh, 2008) has generated one of the most heated debates between academics (see: Acton and Ryder, 2012; Okely, 1983; Matras, 2002) in terms of why Roma left India, when and under which circumstances. It is debateable whether such questions can ever be answered satisfactorily, never mind conclusively.

We must acknowledge that scholarly work on Roma beginning in the eighteenth century has had an impact of how Roma are seen and treated today (Van Baar, 2011: Chapter 3) including on societal and politico-legal representations. This article argues that we should view Roma as a political identity rather than try and work out who is an authentic or 'real' Roma/Gypsy/Traveller. A focus on political identity means that we can explore the meaning of diverse representations of Roma and emphasise the fluidity of belonging for individuals. Vermeersch (2008: 361) notes that representations of Roma as a clearly delineable people carry an emancipatory message that advocacy groups and governmental bodies promote but warns of the negative implications of such clamorous politicisation'. Academics should be careful not to represent Roma as a coherent bloc, not only because of their contested origins and history, but because what it means to be Rom is subjective and relational; arising as it does through processes of socio-cultural exchange. Roma, like 'the majority' is not a monolithic unit that thinks, acts, and feels the same way.

For their part, anthropologists have explored Roma culture through ethnographic studies detailing the performance and meaning of Roma identity (Gay y Blasco, 1999; Lemon, 2000; Okely, 1983; 
Stewart, 1997) which has elaborated on the diversity of Roma culture. Ethnographic representations of Roma have traditionally emphasized the role of the individual as exemplar and performer of Roma distinctiveness (Gay y Blasco, 2011: 445). By examining the meaning of Roma identity, anthropologists have demonstrated that identity is a process, a performance, and does not exist a priori. Political scientists have examined the political disunity of Roma and the various structural obstacles which impede the ability of Roma to formal political representation (McGarry, 2010; Vermeersch, 2006). The construction of a Roma nation or a Roma identity by political entrepreneurs and the recognition of this political identity has meant Roma are increasingly seen as a political project involving Roma and non-Roma political actors. Any attempt to understand Roma representation must resolve how 'we', i.e. academics, NGOs, international organisations, advocacy networks, charities, public officials, governments and society at large, interact with 'them'. Roma thus become objects of research and policymaking, a puzzle to be solved, a problem to be fixed. Roma as objects are shaped by discourse (Simhandl, 2006, 2009) which imposes boundaries between Roma and non-Roma and ascribes negative associations on group identity. Greenfields and Ryder (2012) point out how important it is to include the active participation of voiceless groups such as Roma in research lest their needs be distorted. The presence of 'a Romani voice' within research is crucial so that Roma do not remain mere objects of research but become active players in informing research agendas. Nevertheless, the question of who/what constitutes 'Romani voice' continues to be debated and can easily slip into essentialising notions of authenticity. There can be no guarantees that any person can constitute 'a Romani voice', as Harris and Rampton (2009) argue, ethnicity comes without guarantees.

The political identity of Roma is bound up with how Roma are understood by the majority ${ }^{1}$ (including society, governments, and international organisations) as well as in research. Since the mid-1990s, Roma have become a political project imagined and sustained by non-Roma, such as civil society and national and international advocates, but has also included Romani elite, which has had a crucial role in elevating Roma up the political agenda in the European Union (EU) and its member states. States and international organisations want to know who they are speaking to and how to measure the success of policy interventions thus 'the Roma' as a political project was born. Since the 1970s Roma activists and advocates working through the International Romani Union and the Roma National Congress have been keen to adopt this appellation believing it preferable to 'Gypsy' and hopeful that it would help attain recognition of the demands of Roma transnationally and by extension nationally, and secure rights which had remained out of reach. Difficult questions such as 'who are Roma?',

\footnotetext{
${ }^{1}$ It should be noted that not all members of the majority project negative images on Roma identity, what I mean here is the majority of the majority.
} 
'what are the criteria to determine who is Roma?' or 'how many Roma?' soon collapse under the ontological and methodological weight which these questions engender. But we can research Roma as an explicitly political project by exploring the relationship between identity, inclusion and policy, and can set aside problematic ontological questions. There exists a separation between Roma as a group of diverse individuals and cultures in which self-determination and self-ascription are key on the one hand, and the political identity of Roma which is constructed as more coherent, on the other. These dual processes of identity construction are not just reproduced in different political contexts but also involve numerous actors with diverse motives.

In order to understand the relationship between Roma representations (representation of) and the ability of Roma to voice their demands in public life (representation for), it is first necessary to consider some prominent representations of Roma which have emerged. Roma have been, and continue to be, constructed and imagined in multiple contradictory, self-serving and strategic ways. The outcome is a swathe of images projected onto Roma communities by the majority which I refer to here as 'representations'. This article considers two types of Roma representations: societal and politico-legal representation. Societal representations of Roma run the gamut of negative and positive images but are overwhelmingly unfavourable and are constructed and sustained by the majority non-Romani population. These representations serve to reinforce the idea that Roma are different or do not 'fit' in various national and transnational political contexts. However, this does not mean that the voice of Roma is absent completely: there is a long history of Romani selfrepresentations as political actors but recently Roma activists have become much more vocal and have challenged dominant hetero-representations. Politico-legal representations of Roma are elaborated by international organisations, national governments, NGOs, and have some input from Roma elite and have clear repercussions for policymaking, including those which promote the inclusion of Roma.

Acknowledging that over-emphasising the perceived 'difference' of Roma in public and academic discourse is ineffectual (Tremlett, 2012), I argue that the various permutations of Roma identity serve to highlight their 'otherness' in the eyes of the majority which makes inclusion of Roma communities all the more difficult. The article then considers how the stigmatisation of Roma identity lies at the heart of Roma representations and argues that any attempt to formulate policies for Roma inclusion (in health, housing, education, employment, etc) requires the active participation, voice and presence of Roma in public life. It concludes with insights on inclusion, identity and Roma representations.

\section{Societal representations of Roma}


Today, it is not hard to find a newspaper article warning of the influx of Roma migrants, problems of begging in major European cities, or of supposed Gypsy criminality. Roma communities are more visible than ever before but have been marked as a problem: a problem for the majority who have to live with such unsavoury elements in their midst. Whilst this list is not intended to be exhaustive, there are multitudinous representations of Roma which are produced, sustained and consumed by the majority including: nomads, migrants, underclass, poor, backwards, parasitic, marginal, anachronistic, criminal, deviant, musical, work-shy, beggars, threatening, victims, and dangerous. Such representations of Roma matter. The representation of Roma as a problem community is historically grounded and has justified assimilation, slavery and genocide at one extreme and persecution and marginalisation at the other. The negative representations of Roma are more than a historical artefact, remaining very real today. For example, we can link the representation of Roma as criminal and deviant by the media in Italy to the hate speech elaborated by politicians and subsequent hostile policies targeting Roma settlements to be destroyed and Roma to be fingerprinted (Amnesty International, 2008). In 2010, the French government initiated a security discourse which constructed Roma as a deviant population which threatened the social fabric of the nation and justified the expulsion of Roma from France, who had not secured work within the designated three-month window (McGarry and Drake, 2013). Whilst representations of Roma as deviant, threatening, and criminal have clear implications for the treatment of Roma by the state, this section will explore the dominant societal representations of Roma identity.

Roma, as a political project or phenomenon, has been constructed as an attempt to challenge the negative ascription of Roma identity, even as it appears, prima facia, to reinforce their difference. Implicit in this challenge is changing the meaning and content of Roma identity including how Roma are seen, categorised, understood, and treated by the majority. Conceiving of Roma as a political identity has the potential to accommodate their difference even as it permits representations to inform public discourse. How political identity is presented through formal representation is vital and must emphasise how Roma and the majority share similar hopes and aspirations (health, family, work, opportunity, happiness). Thus, Roma activists and advocates try to raise the political consciousness of the group by debunking negative stereotypes such as those listed above. All stereotypes are inaccurate, even the positive ones celebrating the purported skill of Romani musicians, in the sense that they imply a homogeneity, a coherence we would not expect for any group (Vermeersch, 2008). Roma occupy an inferior social position as an excluded minority group due to the negative representations of Roma identity 'especially in Eastern Europe, where words like Tzigan, Zingaro, Zigeuner always carried a stigma of inferiority' (Gheorghe, 1997: 158). Societal representations of Roma maintain the symbolic and physical boundaries between Roma and the 
majority and maintain a relationship which is based on control, oppression, and exclusion. In Italy, the depiction of Roma as 'nomads' fuels the idea that Roma ought to live in camps, physically isolated from Italian society which 'reinforces the idea that Roma are not Italians and do not "belong" to Italy' (Sigona, 2005: 746).

Roma have become a population which the majority can dominate and exclude, making them a target onto which people can vent their frustrations and project their fears (Stewart, 2012). Lacking strong political agency through mobilisation (representation for), Roma are unable to adequately challenge such representations. Stewart (2012: 4) usefully points out that it is not Roma who are targets but it is more subtle forms of domination which represents Roma culture as an aberration, thus Roma culture is in conflict with the majority's culture: 'it is no accident...that it is the image of "criminal Roma" or "workshy Roma" - rather than Roma per se - that provides one of the clarion calls of the new xenophobic politics'. Thus, Roma representations (what Stewart calls 'images') construct Roma not just as different, which multiculturalist policies should be able to accommodate, but as 'agents of disorder or bearers of an unspecified "threat" to national identity' (Stewart, 2012: 5). The latter phenomenon was paraded in full view during the French Roma expulsions of 2010. The use of representations allows the majority to construct and sustain images of a given population without explicitly targeting them. Similarly, African Americans are seen as criminals and dangerous, gays as perverted or upsetting the 'natural' order of things and migrants as leeching off the state. It does not matter particularly whether such representations are 'true' or can be proven (they cannot), it only matters that they exist in public discourse becoming tacitly accepted because of relationships which reproduce the negative ascription of group identity.

Horváth (2012) captures the significance of negative ascription of group identity. In Hungary, Roma are referred to as 'Gypsy' and this categorisation has reinforced their difference vis-à-vis the majority Hungarian population, even though these Gypsies are Hungarian too. Through the elaboration of discourses and stereotypes, boundaries are maintained which create an understanding of the relationship between Gypsies and 'Hungarians'. The central feature of this interaction is that Gypsies occupy an inferior position and to be called Gypsy is to be stigmatised. Horváth (2012: 123) argues that Gypsies live their lives in a state of continuous adaptation and orientation to the majority, falsely believing that eroding difference will result in inclusion ${ }^{2}$. Across Europe, a common rallying call amongst the majority and promoted by politicians eager to deflect blame for policies which have failed to induce meaningful Roma inclusion at home, is that Roma are to blame. It is Roma who are apparently unwilling to integrate and to adapt to the norms and rules

\footnotetext{
${ }^{2}$ The impact of representations on Roma on the ground will manifest in different ways which can only be uncovered through ethnographic research.
} 
of society. Such claims are not realised in practice however: Roma are represented as 'socially disadvantaged' which allows the education system in the Czech Republic to continue to segregate Roma and non-Roma school children despite a 2007 European Court of Human Rights ruling (ERRC, 2013: 20-26). The ascription of group identity as inferior ('socially disadvantaged') marks some Roma out for special treatment by the state where they are segregated from the majority in education which, in turn, reinforces symbolic and physical boundaries between Roma and nonRoma.

Roma are expected to conform (whilst policy marks them as different and in need of special treatment) and failure to do so will result in continued marginalisation and persecution, but the choice is presented as theirs. The representation of Roma as inadaptable clearly marks any problems they face as their own fault. It is important to note that this blame is ascribed onto Roma identity: the perceived inadaptability of Roma under communism and capitalism suggests that Roma are not able to adapt, irrespective of the economic and political system thus 'Roma marginalisation is frequently problematised in terms of culture and behaviour' (Van Baar, 2011: 198). Csepeli and Simon (2004: 133) maintain that 'the presence of begging Roma and of homeless Roma children sniffing glue on the streets has strengthened the stereotypes that Roma are socially disembedded', instead of asking what structural barriers make such outcomes possible. After years of policies, laws, activism, advocacy, the establishment of representative organisations, training, funding, and capacity-building projects, there is a general consensus that the situation of Roma has not improved. The notable gap between Roma and non-Roma in terms of wealth, education, employment, and life expectancy remains. Due to the inferior position Roma occupy and enduring negative representations which reinforce their marginality, it is hardly unsurprising that policies aimed at inclusion have not met with success. However, Roma have become more prominent on the political stage, with a growing awareness of the multiple and inter-related problems facing Roma communities, and a gradual awakening of Roma political consciousness.

\section{Romani voices and self-representations}

Whilst hetero-representations of Roma are dominant in the public sphere, Roma selfrepresentations have become more prominent as a reaction to negative stereotypes which signals a growing political consciousness and capacity to take ownership of how Roma communities are understood by themselves and by others. Whilst it is important for Roma agency to be at the forefront, an authentic, unified 'Roma voice' is not possible. Indeed, discursive interventions by individual Roma do not signify a form of Roma identity absolutism but could be understood as acts of communication which can invoke or produce the resources, capacities and ideologies which 
resonate with other Roma. Romani academic and activist lan Hancock (2010: 17) points out why hetero-representations have become so dominant maintaining it is the 'vagueness regarding Romani identity that has allowed it to be so casually manipulated by outsiders' meaning non-Roma have a degree of power in constructing the dominant images of Roma. He further argues that instead of thinking negatively in terms of identity, about the things that make one group different from another, we must think instead of what all of us share, in terms of language, culture and ancestry...[T]he characteristics that divide us now have all been acquired from the non-Romani world' (2010: 21). Such a conviction holds that societal representation of Roma can be challenged by focusing on a supposedly shared culture. However, the recently deceased Nicolae Gheorghe (2013: 48) notes: '[O]ur identity and memories of being tigan were based more on the experience of discrimination and external stereotypes, less on commonly shared meanings of being Roma in a vernacular, ethnic sense'. He maintains that, 'representations of Roma culture are often simply responses to other people's expectations of the performance of otherness' (Gheorghe 2013: 50), meaning that Romani self-representations are relational and require the recognition of others. Whilst Gheorghe does not suggest that Romani self-representations should be based on a common experience of discrimination and external stereotypes, he does acknowledge the pervasiveness of hetero-representations in the construction of Roma identity.

The recent cases of reported child abductions by Roma in Greece and Ireland recently reveal the virulent hostility towards Roma and the extreme racism which generated widespread criticism from Roma activists such as Željko Jovanović (2013a) who used the opportunity to highlight the reluctance of many Roma to identify as such (in the national census) for fear that it could lead to discrimination. In the face of evictions, expulsions, ethnic profiling, hate speech, anti-Roma protests, it is difficult to argue with Jovanović's assertion, 'we, the Roma, are a people mired in oppression' (2013b: 191), meaning that self-representations, where they exist, must negotiate this negative ascription. Similarly, the European Roma and Traveller Forum (2011) made a statement on rising anti-Gypsyism: 'The Roma have been depicted as illiterate and unwilling to integrate, encompassing the perfect image of what is going bad in our societies' which reinforces the impact of negative ascription of Roma identity. It continues by simultaneously highlighting the victimhood of Roma and ascribing blame onto non-Roma: 'deprived of proper education and excluded from the labour market, they are branded as parasites of the same societies that have marginalised and oppressed them for centuries'. This statement by one of the most prominent Roma organisations in Europe captures some of the central elements in the societal representation of Roma and demonstrates the utility of representation for to articulate Romani self-representations. 
Aside from the predictable criticisms of discrimination and persecution discussed above there have been a number of critical interventions concerning the role of Roma in fostering inclusion. Acknowledging that 'it takes two to tango', András Bíró (2013: 9-10) argues that 'attacking exclusively the prejudices and stereotypes of majority attitudes - unacceptable as they are - and ignoring Roma's own weaknesses reproduces, in my view, the victimhood stance which blocks action and "explains" the impossibility of changing the status quo'. He is critical of the ambivalent attitude of Roma officials to the reported increase in petty crime among unemployed Roma in villages and cities, which is blamed on widespread poverty. He argues that 'their acceptance of such delinquency as a normal response to harsh economic situations, strengthens the community's self-image as victims. Worse still, accepting delinquency as an ethnic characteristic (Roma are poor, so they steal!) offers a justification for racism' (2013: 35). Recently, there has been a desire to call attention to controversial topics such as the human trafficking, gender inequalities, begging, and the practice of early marriage within some traditional communities. Gheorghe (2013: 43) maintains that, in certain cases where Roma deserve blame, Roma activists intervene and demand that racist statements be condemned but this strategy 'conveys the message that Roma cannot be criticised', asking 'Do I betray my people if I say so?' (46). The danger of such self-representations is that they could be used by those hostile to Roma integration efforts to reinforce negative ascriptions of Roma identity as backward and criminal.

Roma scholar and activist Angéla Kóczé (2013: 8) believes that 'people in marginalised communities are affected by the majority's perception of the minority-this has an effect on the minority as well'. One effect can be a positive reframing of Romani self-representations, beyond challenging discrimination and persecution. It is not just discursive interventions of Roma activists which have challenged societal representations of Roma. Recent years have witnessed two initiatives to articulate a different representation of Roma in the public sphere. First, Barvalipe is a summer school on Roma Pride organised by Roma and supported by Open Society Foundations which is in its third year. It intends to provide young Roma with a powerful experience and encourage them to choose to serve as role models, political leaders and civic activists able to advocate for themselves and their communities in the future (see: http://www.opensocietyfoundations.org/grants/barvaliperoma-pride-summer-school). Secondly, and also in its third year, is the nascent transnational Roma Pride movement, which has grown since its inception in 2011 and in 2013 witnessed events (including demonstrations and talks) in sixteen states. Roma Pride was initiated by an anti-racist NGO, European Grassroots Anti-Racist Movement, and brings together Roma and non-Roma activists to raise awareness of Roma issues across Europe. Both can be seen as attempts to challenge dominant ascriptions of Roma identity although Roma Pride protests are more visible expressions of 
solidarity and signify attempts to raise a political consciousness of Roma in different European states. The director of Roma Pride in Prague does not believe that such protests can challenge the negative stereotypes of Roma but does believe it offers the opportunity to make a stand with other Roma (personal interview with Ivanka Mariposa Čonková $9^{\text {th }}$ December 2013).

There have been efforts to capitalise on the attention given to Roma by governments and international organisations since the mid-1990s which carry political and legal authority but any representation for Roma must negotiate the prevalent negative representations of Roma. The next section considers efforts to represent Roma in the public sphere which must negotiate and challenge the negative ascription of Roma political identity described above.

\section{Politico-legal representations of Roma}

We have considered how societal representations of Roma can impact on their inclusion so let us now deliberate how political conceptions and legal definitions of Roma can impact on how they are categorised and understood. No other minority group in Europe can claim to have been represented in such divergent ways which makes Roma an interesting case study for exploring the impact of political identity and representation on policy-making interventions for inclusion. The representations of Roma as a nation, an ethnic group, a national minority, a transnational group, and a European minority have been the result of responses to politico-legal norms, values and opportunities available to Roma and non-Roma actors. These actors include Roma through activism and representative organisations, usually NGOs, as well as the majority, including national governments and international organisations. Sometimes, Roma elite have propagated a particular representation for strategic reasons whilst at other times they do not appear to have much control. Roma elite, in the form of self-appointed spokespersons, experts, elected representatives, and activists have embraced many of these representations at one time or another with the hope that it will remedy widespread socio-economic and political exclusion. The absence of rigorous scrutiny of such representations and the eagerness to adopt multiple representations has meant that it is unclear who Roma are and what their demands are, and by extension, it has revealed the absence of a clear strategy for dealing with the problems facing Roma across Europe. In turn, potentially harmful representations have not only filtered through but have been embraced. The upshot is competing and sometimes contradictory policy solutions: obviously the policy interventions to foster inclusion of a national minority are very different from those elaborated for a European minority. This section considers national and transnational representations of Roma and the opportunities generated by such representations from a policy perspective. 
The legal definition of Roma will determine, to a great extent, their treatment by the state as well as how they are understood by the majority. To take one historical example, Roma in Romania were slaves until the mid-nineteenth century and designated as chattel property in legal codes. Gheorghe explains (1997: 158-159) that 'Tsigane in the Romanian language was equivalent with rób which might be translated as "slave". So it was a social identity, much more than an ethnic cultural identity, marking...an inferior social position, a legal segregation between Gypsies and non-Gypsies'. The boundaries between Roma and non-Roma are sustained by legal norms which represent Roma as inferior to non-Roma. Liégeois (1994: 199) argues that 'the image of the stranger and of the strange, updated every few years, exposes the fears and worries of those who create it, by giving shape to the group's idea of its "opposite" which they project onto the strange'. He maintains that we can tell a lot about the political climate of a time by how Roma are represented. This boundary maintenance is evident today. The attempt to anchor Roma in the national context through their recognition as a national minority or an ethnic minority carries more than symbolic weight. Official legal recognition as a national minority (Bosnia-Herzegovina Croatia, Romania, Serbia, Slovakia, Sweden) or an ethnic minority (Bulgaria, Hungary, Slovenia) reveals more about broader socio-political concerns, particularly the spread of inter-ethnic conflict, potential secessionist claims, and the rise of nationalism in eastern Europe since the 1990s than it does about any desire to include Roma. Certainly, the formulation of any policy is made easier when applied to a group with the legal status as a minority but Roma do not fit the definition of a national minority because they do not possess a kin state or a homeland. A tension exists between how Roma are legally defined in the national context and how responsibility is attributed in the international political arena. One strange result is that one of the most prominent institutions on minorities in Europe, the Organisation for the Security and Cooperation in Europe's (OSCE) Office for National Minorities, pays little attention to Roma issues because these do not fall within its conflict and national minority remit, even though Roma are often the victims of violence and are recognised as a national minority in many OSCE member states.

Let us now turn to the dominant representation of Roma today: Roma as a European minority. Recent research has examined how the construction of Roma as a transnational or European minority has impacted on integration efforts in the national political context (McGarry, 2011; Vermeersch, 2012). The presentation of Roma as a European minority can only be understood as the product of more established political processes initiated by Roma elite ${ }^{3}$ in the 1970s which constructed Roma as transnational nation. The creation of representative organisations such as the

\footnotetext{
${ }^{3}$ The construction of Roma as a European minority is an elite-driven process with no real input from Roma communities who lack effective agency and ownership of their political identity.
} 
International Romani Union (IRU) (1971) attempted to unite Roma across national borders and the ideological divide between east and west Europe, and foster solidarity through proto-typical national-building initiatives such as the creation of a flag. In the 1990s, as international NGOs such as Human Rights Watch began to raise awareness of 'the Roma issue' and demand that international organisations such as the OSCE, EU, and the Council of Europe, pay more attention to their needs, Roma activists saw an opportunity for a new audience which would be more receptive to their claims. Here the voice of Roma was articulated through representation structures which attempted to present the needs of Roma communities to the international political community. Thus, Roma gradually came to be regarded as a transnational issue. If national governments were unwilling to address the marginalisation and discrimination of Roma then Roma activists and advocates would circumnavigate local and national political agencies and articulate their demands in the transnational political context.

As eastward expansion of the EU began in the late 1990s, the transnational dimension to the Roma issue was acknowledged by EU policymakers who were keen to ensure that Roma did not migrate westwards on EU accession (Guglielmo and Waters, 2005). In 2001, at the IRU World Congress, delegates announced the 'Declaration of the Nation' where it affirmed the status of Roma as a nation without a territory (Acton and Klímová, 2001). Implicit in such a representation is that Roma are a special case and require formal representation in order to articulate their demands. Mirga and Gheorghe (1997: 22) cautiously warn of the danger of representing Roma as a stateless nation because it fuels the image of Roma as not constitutive of the dominant nation and not full citizens of the states in which they reside. The implication of such an approach is that states are relieved of their obligation to protect Roma and can instead rely on the international political community, such as the EU and Council of Europe, to address their interests. Moreover, Kovats (2003) maintains that Roma nationalism provides the basis for the ideological, political and institutional dislocation of Roma minorities from majority nations, thus indirectly absolving governments of responsibilities towards all its citizens. So, representations as a nation, a transnational minority or a European minority highlight the distinction between Roma and the majority, shifting the discussion to one of responsibility for inclusion.

In 1993, the Council of Europe declared that Roma are 'a true European minority' in Resolution 1203. Since then, the representation of Roma as European has been affirmed through successive discursive interventions including 'policy documents, human rights reports, political speeches, transnational activism, media coverage, scholarly studies and the like' which has conspired to 
'Europeanise their representation' (Van Baar, 2011: 16) and highlights the popularisation of Roma as a transnational minority belonging in the European political context. An 'EU Framework for National Roma Integration Strategies Up to 2020' was launched in late 2011 to encourage member states to take more responsibility for Roma within their territories. The establishment of the European Roma and Traveller Forum, European Roma Information Office, European Roma Rights Centre, European Grassroots Organisations Network, and the European Union Roma Policy Coalition demonstrates how attractive the designation 'European' has become for Roma activists and advocates. It communicates the European dimension of the struggle for Roma inclusion whilst opening up new possibilities, agencies and powers beyond the nation-state. However, as a political identity, the representation of Roma as European is a double-edged sword. Vermeersch (2012: 1197) points out that Roma are represented as a special case, a particular puzzle which needs to be solved but the 'new tendency to single out the Roma as a European priority and a special European concern has also, rather paradoxically, opened up new opportunities for nationalist politicians to plead against new national measures to help the Roma' (emphasis in original). It also affords national policymakers the option of ignoring the needs and interests of Roma due to the belief that Roma are a special European case which ought to be dealt with at the EU level. So, representation for Roma takes place in the transnational political context where the sobriquet 'European' provides an opportunity for Roma elite to articulate their demands in a more receptive political environment than the national political context, but meaningful policies which can facilitate Roma inclusion can be implemented only in the local and national arena, not the transnational European context.

\section{Stigmatisation and political representations of Roma identity}

Representations of Roma are rarely in the hands of Roma themselves but are subject to prevailing images projected onto Roma by the majority. Responses to stigma can weaken symbolic boundaries between groups (by downplaying differences) but can also result in a greater rigidity (when group membership is affirmed and defined in opposition to that of out-groups) (Fleming et al., 2012: 410). Representations of Roma, both societal and politico-legal, have stressed their difference, and it is safe to say that these do not help foster inclusion (Tremlett, 2012). At present, the power to change the representation of Roma remains in the hands of the majority because Roma are 'so politically weak that they can hardly dispute the official image of them that we may construct' (Sigona, 2005: 747). The point of departure for this section is that social identities (Jenkins, 1996) result from selfidentification (what it means for Roma to identify as such) as well as group ascription (the categorisation given to Roma by non-Roma). Sociological understandings of Roma identity argue that representations of Roma are the product of processes of oppression which can only lead to the 
formation of an identity based on the perception of the majority. Csepeli and Simon (2004: 136) note the various constructions of Roma identity, including as an ethnic group, a cultural group and a social class, arguing that 'the losers of the struggle for the right of identification were the Roma themselves, whose voice was not heard'.

By focusing on the political identity of Roma we can place Roma agency at the forefront outlining how Roma have attempted to negotiate the meaning of their group identity. In this way, we move beyond conceptions of preferential treatment and positive discrimination prescribed by others for minority groups (Young, 1990) and Roma in particular (Baclija et al., 2008) which demand representation for Roma. Roma agency (representation for) draws its authority from claims to a shared solidarity, which we know is patently missing from Roma communities. Yet, we must exercise caution on how the political identity of Roma is constructed: Roma are encouraged by national governments and international organisations to present a united front in the public sphere, and failure to do so could mean their needs and interests are side-lined or ignored completely. Thus Roma elite attempt to foster solidarity whilst appealing to shared experiences of stigmatisation which can serve to reinforce their difference.

Formal political representation is important so that Roma can articulate their interests in a variety of political contexts (McGarry, 2010) but it must be supported and informed by how Roma negotiate their political identity. This means that Roma have a presence in public life but also take ownership of how they are represented. The dilemma here is to change the meaning of their group identity, which is made more difficult by the lack of consensus on who Roma are as well as the deeply entrenched negative ascriptions of Roma identity. Roma do communicate representations of their group identity but usually not in circumstances that they choose because the majority establishes the rules of the game. The central challenge for Roma, then, is to challenge the denigration of their group identity in local, national, and transnational contexts and to raise the political consciousness of Roma across Europe. Political representation must build solidarity across an extremely heterogeneous community in order to change the meaning and content of their group identity, debunk stereotypes, and project a positive image which will resonate with the majority. It is not enough for Roma to demand fair treatment because such claims have been made in the past, and have been ignored.

Roma as an endonym acts as an umbrella term which houses a vast number of groups and subgroups including Sinti, Manouche, Lovari, Traveller, Gitano, Ashkali, amongst others. Roma therefore attempt to present a united front to the international community which aids the formulation of policy and legal interventions. What these groups do share is a common experience of persecution 
in various European states but it is questionable whether this common experience is sufficient to generate bonds of solidarity. Roma representation has the potential to reveal how political identity is managed by the group. Hall (1996: 6) maintains that identity requires a 'process of becoming rather than being: not "who we are" or "where we come from", so much as what we might become, how we have been represented and how that bears on how we might represent ourselves.' There is a danger that stigmatised groups accept the representations projected onto them which can, in turn, become self-fulfilling prophecies. However, time and time again stigmatised groups have actively challenged these representations and in the process negotiated their collective identity and symbolic boundaries (Lamont and Fournier, 1992), changing how they are seen by others and how they see themselves. The key task of representation for Roma is to communicate a conception of Roma identity which captures the heterogeneity of the community otherwise the default representation of Roma as a problem community which does not ' $f i t$ ' remains. But the less fixed an identity is means that it is weaker and thus easier to manipulate by non-Roma actors. As a corollary, any attempt to present a clear political identity is unlikely to foster internal solidarity.

Ultimately, it is the national political context where the representation battles are fought and where meaningful policy-making implementation will take place. Clearly, the representation of Roma as a European or transnational minority carries symbolic value and can help Roma activists and advocates put pressure on national policymakers, presenting Roma as a policy issue beyond national borders. The political identity of Roma is not fixed but should be conceived of as a process which will change over time due to socio-economic, cultural and political circumstances and opportunities. Promoting a coherent political identity of Roma is expedient for activists and advocates keen to find the solutions to the problems facing Roma communities. The central challenge for Roma elite is to change the meaning of their stigmatised identity.

\section{Conclusion}

Roma have been defined, constructed and understood in numerous ways over the years which have hindered efforts to foster the inclusion of Roma across Europe. Societal and politico-legal representations have been constructed by the majority and Roma elite with little input from ordinary Roma. Some representations may appear to offer solutions or may seem benign but can be detrimental to the community in the long-term. The dominant images of Roma are owned and reproduced by non-Roma which construct and sustain Roma as a problematic, parasitic and dangerous community which does not belong in various national contexts. This stigmatised identity is grafted upon a highly heterogeneous group and allows socio-economic and political exclusion. Whilst Roma have attempted to challenge hetero-representations in order to take ownership of how 
Roma are understood, an authentic 'Romani voice' is not possible due the hybridity of Roma identities. It is the political identity of Roma which has the capacity to change through formal representation in the public sphere with Roma actively determining how they are understood. But as I have shown the negative ascription of Roma identity makes representation for Roma more difficult as those who speak on behalf of Roma must deal with widespread societal discrimination and hostility. Identities are not fixed but the challenge for Roma is to reverse years of stereotypes and stigmatisation.

Roma today are best conceived as a discursively constructed political identity sustained and reproduced by an array of actors, some of whom identify as Roma. The multiple public discourses on Roma communities demonstrate how their public representations are prolific and owned by a variety of institutional stakeholders including NGOs, EU institutions, international organisations, and academics. Broadly speaking, Roma communities do not participate in the public representation of their political identity which means that dominant discourses continue to centre on the supposed 'difference' of Roma communities: Roma are nomadic, criminal, deviant, etc. This difference, and the relative absence of a Roma voice through formal representation, allows processes of stigmatisation to continue. Political identity would need to be embraced by individual Roma who affirm their group affiliation which can help challenge negative ascription of their group identity. Identity is in flux, subject to change and the increased affirmation of group identity has the potential to change the meaning and content of Roma political identity. One interesting question to consider is why have political elites embraced the construction of Roma as a political identity and the effects of this? Certainly one of the overall effects is containment, where Roma continue to exist in a parallel society to that of the majority, excluded from the labour market and living on the outskirts of major cities. And yet most national policies are attempting to include Roma, to educate Roma, to secure skills, employment and leadership within Roma communities. Such policies are built on difference, that Roma require special treatment because they are different from us. This context provides fertile ground for 'othering' Roma and stigmatising Roma political identity.

Policies which fail to address the stigmatisation of Roma identity are bound to fail. The article has argued that a distinction between representation for and representation of is helpful because it allows us to understand the context of identity construction, its impact on how Roma are understood, and how the political representation of Roma in public life offers an opportunity to promote inclusion. Policy which aims at inclusion is meaningless at the European level. If Roma are to be included in socio-economic and political life then this can only realistically be implemented at the local and national level which is why the representation of Roma as a European minority is a 
chimera, potentially a means to an end. Roma elite should be wary of adopting representations which they do not design, particularly when certain representations appear to offer immediate solutions. More effort is required to rehabilitate the image of Roma which will require the active participation of Roma as well as the political will of policymakers in the national context: neither of which is unproblematic.

\section{References}

Acton T and Klímová I (2001) The International Romani Union: an East European answer to a West European question? In Guy W (ed) Between Past and Future. The Roma of Central and Eastern Europe. Hatfield: University of Hertfordshire Press, pp. 157-219.

Acton T and Ryder A (2012) Recognising Gypsy, Roma and Traveller History and Culture. In Richardson J and Ryder A (eds) Gypsies and Travellers: Empowerment and Inclusion in British Society. Bristol: Polity Press, pp. 135-149.

Amnesty International (2008) Italy: The Witch-Hunt Against Roma People Must End. Al Index 30/0006/2008. London.

Baclija I, Brezovsek M and Hacek M (2008) Positive Discrimination of the Roma: The Case of Roma Local Councillors in Slovenia. Ethnicities 8(2): 227-250.

Bíró A (2013) The Price of Roma Integration. In Guy W (ed) From Victimhood to Citizenship: The Path of Romani Integration. A Debate. Budapest: Kossuth Kiadó, pp. 10-39.

Csepeli G and Simon D. (2004) Construction of Roma Identity in Eastern and Central Europe: Perception and Self-Identification. Journal of Ethnic and Migration Studies 30(1): 129-150.

European Roma Rights Centre (ERRC) (2013) Czech Republic: A Report by the ERRC. Country Profile 2011-12. Available at: http://www.errc.org/cms/upload/file/czech-republic-country-profile-20112012.pdf (accessed 14 May 2014).

European Roma and Traveller Forum (ERTF) (2011) Statement on Anti-Gypsyism in Council of Europe Member States. Presented at the CAHROM meeting in Istanbul on 23 November. See: http://www.ertf.org/images/stories/documents/ERTF Statement CAHROM 23112011.pdf (accessed 14 May 2014).

Fleming C, Lamont M and Welburn J (2012) African Americans Respond to Stigmatisation: The Meanings and Salience of Confronting, Deflecting Conflict, Educating the Ignorant and 'Managing' the Self. Ethnic and Racial Studies 35(3): 400-417.

Gay y Blasco P. (1999) Gypsies in Madrid: Sex, Gender and the Performance of Identity. Oxford: Berg.

Gay y Blasco P (2011) Agata's story: singular lives and the reach of the "Gitano law". Journal of the Royal Anthropological Institute 17: 445-461.

Gheorghe N (1997) The Social Construction of Romani Identity. In Acton T (ed) Gypsy Politics and Traveler Identity. Hatfield: University of Hertfordshire Press, pp. 153-163. 
Gheorghe N (2013) Choices to be Made and Prices to Be Paid: Potential Roles and Consequences in Roma Activism and Policy-Making. In Guy W (ed) From Victimhood to Citizenship: The Path of Romani Integration. A Debate. Budapest: Kossuth Kiadó, pp. 40-97.

Greenfields M and Ryder A (2012) Research with and for Gypsies, Roma and Travellers: Combining Policy, Practice and Community in Action Research. In Richardson J and Ryder A (eds) Gypsies and Travellers: Empowerment and Inclusion in British Society. Bristol: Polity Press, pp. 151-167.

Grellmann $\mathrm{H}$ (1787) Dissertation on the Gypsies, being a historical inquiry concerning the manner of life, family, economy, customs, conditions of this people in Europe, and their origin. London: G. Bigg.

Guglielmo R and William Waters T (2005) Migrating towards Minority Status: Shifting European Policy towards Roma. Journal of Common Market Studies 43(4): 763-786.

Hall S (1996) Introduction: Who Needs Identity? In Hall S and Du Gay P (eds) Questions of Cultural Identity. London: Sage, pp. 1-17.

Hancock I (2000) The Emergence of Romani as a Koïné Outside of India. In Acton T (ed) Scholarship and the Gypsy Struggle: Commitment in Romani Studies. Hatfield: University of Hertfordshire Press, pp. 1-13.

Hancock I (2010) Roma Today: Issues and Identity. In Kyuchukov H and Hancock (eds) Roma Identity. Prague: Slovo 21, pp.13-25

Harris R and Rampton B (2009) Ethnicities Without Guarantees: An Empirical Approach. In Wetherell $\mathrm{M}$ (ed) Identity in the $21^{\text {st }}$ Century: New Trends in Changing Times. Houndmills, Basingstoke: Palgrave Macmillan.

Horváth K (2012) Silencing and Naming the Difference. In Stewart M (ed) The Gypsy Menace: Populism and the New Anti-Gypsy Politics. London: Hurst, pp. 117-135.

Jenkins R (1996) Social Identity. London: Routledge.

Jovanović Ž (2013a) Maria is Roma - so now she will become invisible once more. The Guardian, 28 October. http://www.theguardian.com/commentisfree/2013/oct/28/maria-roma-invisible (accessed 14 May 2014).

Jovanović Ž (2013b) Values, Leadership, Power. In Guy W (ed) From Victimhood to Citizenship: The Path of Romani Integration. A Debate. Budapest: Kossuth Kiadó, pp. 190-197.

Kóczé A (2013) Ratiu Democracy Award Winner Fights 'Anti-Gypsy' Prejudice. Washington Post, 5 November. (Interview by Hunter L J). http://www.washingtonpost.com/blogs/she-thepeople/wp/2013/11/05/ratiu-democracy-award-winner-fights-anti-gypsy-prejudice/ (Accessed 16 May 2014).

Kovats M (2003) The Politics of Romani Identity: Between Nationalism and Destitution, OpenDemocracy: Free Thinking for the World. http://www.opendemocracy.net/peoplemigrationeurope/article 1399.jsp (accessed 16 May 2014).

Lamont M and Fournier M (eds) (1992) Cultivating Difference: Symbolic Boundaries and the Making of Inequality. Chicago: University of Chicago Press.

Lemon A (2000) Between Two fires: Gypsy Performance and Romani Memory from Pushkin to Postsocialism. Durham, N.C.: Duke University Press. 
Liégeois JP (1994) Roma, Gypsies, Travellers. Strasbourg: Council of Europe.

Marsh A (2008) History, Historiography and the Origins of the Gypsies. PhD thesis, University of Greenwich, UK.

Matras Y (2002) Romani: A Linguistic Introduction. Cambridge: Cambridge University Press.

McGarry A (2010). Who Speaks for Roma? Political Representation of a Transnational Minority Community. London: Continuum.

McGarry A (2011) The Roma Voice in the European Union: Between National Belonging and Transnational Identity. Social Movement Studies 10(3): 283-297.

McGarry A and Drake H (2013) The Politicisation of Roma as an Ethnic 'Other': Security Discourse in France and the Politics of Belonging. In Korkut U, Bucken-Knapp G, McGarry A, Hinnfors J and Drake $\mathrm{H}$ (eds) The Politics and Discourses of Migration in Europe. NYU Transitions in Europe Series. New York: Palgrave, pp. 73-91.

Mirga A and Gheorghe N (1997) The Roma in the Twenty-First Century: A Policy Paper. Princeton, NJ: Project on Ethnic Relations.

Okely J (1983) The Traveller-Gypsies. Cambridge: Cambridge University Press.

Sigona N (2005) Locating 'The Gypsy Problem'. The Roma in Italy: Stereotyping, Labelling and 'Nomad Camps'. Journal of Ethnic and Migration Studies 31(4): 741-756.

Simhandl K (2006) 'Western Gypsies and travellers' - 'Eastern Roma': The Creation of Political Objects by the Institutions of the European Union. Nations and Nationalism 12(1): 97-115.

Simhandl K (2009) Beyond Boundaries? Comparing the Construction of the Political Categories 'Gypsy' and 'Roma' Before and After EU Enlargement. In Sigona N and Trehan N (eds) Romani Politics in Contemporary Europe: Poverty, Ethnic Mobilisation and the Neoliberal Order. Basingstoke: Palgrave, pp. 72-93.

Stewart M (1997) The Time of the Gypsies. Boulder, Colo.: Westview.

Stewart M (2012) Populism, Roma and the European Politics of Cultural Difference. In Stewart M (ed) The Gypsy Menace: Populism and the New Anti-Gypsy Politics. London: Hurst, pp. 3-23.

Tremlett A (2012) "Here are the Gypsies!" The importance of self-representations \& how to question prominent images of Roma minorities. Ethnic and Racial Studies 36 (11): 1706- 1725.

Van Baar H (2011) The European Roma: Minority Representation, Memory and the Limits of Transnational Governmentality. PhD Thesis, University of Amsterdam, Netherlands.

Vermeersch P (2006) The Romani Movement. Minority Politics and Ethnic Mobilisation in Contemporary Central Europe. Oxford: Berghahn Books.

Vermeersch P (2008) Exhibiting Multiculturalism. Third Text 22(3): 359-371.

Vermeersch P (2012) Reframing the Roma: EU Initiatives and the Politics of Reinterpretation. Journal of Ethnic and Migration Studies 38(8): 1195-1212. 
Willems W (1998) In Search of the True Gypsy: From Enlightenment to Final Solution. Abingdon: Routledge.

Young IM (1990) Justice and the Politics of Difference. Princeton, NJ: Princeton University Press. 